\title{
FAKTOR YANG MEMENGARUHI PENERAPAN PROTOKOL KESEHATAN 5M DI PASAR TRADISONAL TODOPULI KOTA MAKASSAR
}

\author{
Factors Affecting The Implementation Of The $5 \mathrm{~m}$ Health Protocol In Todopuli Traditional \\ Markets Makassar City \\ Asrijun Juhanto, Rahmawati Azis, Mia Sumarsela \\ Sekolah Tinggi IImu Kesehatan Tamalatea Makassar \\ asriiun@stiktamalateamks.ac.id
}

\begin{abstract}
Covid_19 became a pandemic disease in 2019, where handling and prevention can be done by observing health protocols. Compliance with this protocol can be affected by various factors. The purpose of this study was to determine the factors that influence 5M's compliance with the Covid-19 health protocol. This study uses Accidental Sampling, which is a sampling technique based on chance, which was encountered during the research. The population in this study are traders and market visitors with a sample of 108 people. The data obtained, processed in the form of bivariate and multivariate univariate analysis. The results of this study indicate that the relationship between knowledge $(p=0.0024)$, attitude $(p=0.036)$, education ( $(=0.017)$, age $(p=0.008)$, with compliance $3 M$ health protocol at Todopuli Market, Makassar City. The conclusion of this study is that there is an influence of age, education, knowledge, attitudes, and information messages on Covid-19 on compliance with health protocols in the Todopuli market, Makassar city.
\end{abstract}

Keywords: covid-19; obedience; health protocol

\section{ABSTRAK}

Covid 19 menjadi sebuah penyakit pandemi di tahun 2019, dimana penanganan dan pencegahannya dapat dilakukan dengan memperhatikan protokol kesehatan. Kepatuhan protokol ini dapat dipengaruhi oleh berbagai faktor. Adapun tujuan dari penelitian ini adalah untuk mengetahui faktor yang mempengaruhi kepatuhan $5 \mathrm{M}$ terhadap protokol kesehatan Covid-19. Penelitian ini menggunakan Accidental Sampling yaitu teknik penentuan sampel berdasarkan kebetulan, yang ditemui pada saat penelitian berlangsung. Populasi dalam Penelitian ini adalah pedagang dan pengunjung pasar dengan jumlah sampel 108 orang. Data yang diperoleh, diolah dalam bentuk analisis univariat bivariate dan multivariate Hasil penelitian ini menunjukan bahwa hubungan pengetahuan $(p=0,0024)$, Sikap $(p=0,036)$, pendidikan $(p=0,017)$, Usia $(p=0,008)$, dengan kepatuhan $3 \mathrm{M}$ protokol kesehatan di Pasar Todopuli Kota Makassar. Kesimpulan penelitian ini adalah ada pengaruh usia, pendidikan, pengetahuan, sikap, dan pesan informasi Covid-19 terhadap kepatuahan protokol kesehatan di pasar Todopuli kota Makassar.

Kata kunci: covid-19; kepatuhan; protokol kesehatan

\section{PENDAHULUAN}

Data terkonfirmasi aktif dinyatakan positif terinfeksi virus covid-19 dan sementara menjalani masa isolasi atau perawatan di pusat pelayanan kesehatan pada tanggal 20 Agustus 2021 di Provinsi Sulawesi Selatan berjumlah 101.438 orang. (https://covid19.sulselprov.go.id/).

Perilaku dalam menerapkan protokol kesehatan merupakan suatu aktifitas yang dilakukan untuk menjaga diri agar tidak tertular virus corona dengan menjaga kebersihan personal dan sanitasi yaitu 5M; memakai masker, mencuci tangan memakai sabun pada air mengalir, menjaga jarak, menjauhi kerumunan dan mengurangi mobilitas.

Pasar merupakan fasilitas umum yang memiliki potensi sangat besar terjadi penularan virus corona. Beberapa pasar menjadi klaster penyebaran covid-19, Klaster di pasar dapat dicegah dengan menerapkan protokol kesehatan pada pedagang dan pengunjung. Penelitian tentang perilaku protokol kesehatan Covid19 pada pedagang pasar tradisional dipengaruhi oleh usia dan pendidikan sedangkan jenis kelamin tidak mempengaruhi perilaku protokol kesehatan
Covid-19. Meningkatnya umur membuat seseorang semakin matang atau dewasa dan rasa tanggung jawab dan kepeduliannya meningkat. Pedagang yang memiliki umur yang lebih dewasa rasa tanggung jawab dan kepedulian terhadap diri sendiri dan lingkungan meningkat serta mampu menerapkan $5 \mathrm{M}$ di pasar. Seseorang dengan tingkat pendidikan yang lebih tinggi akan lebih mudah menerima dan memahami informasi tentang protokol kesehatan yang didapatkan guna mencegah penularan Covid-19 sehingga mampu merubah perilaku dalam kehidupan seharihari (Istanti \& Erlita, 2021).

Kepatuhan terhadap protokol kesehatan menjadi hal yang sangat penting saat berkunjung di pasar tradisional. Beberapa hal yang mempengaruhi kepatuhan ini adalah, pengetahuan, sikap dan perilaku pengunjung pasar. Selain itu, pendidikan dan usia juga menjadi pertimbangan dalam hal ini. Satu poin penting yang lain adalah peran dari satgas covid-19 dan tokoh masyarakat menghimbau kepada pengunjung pasar agar tetap mematuhi protokol kesehatan. 
Jurnal Sulolipu : Media Komunikasi Sivitas Akademika dan Masyarakat

Vol. 21 No.2 2021

e-issn : 2622-6960, p-issn : 0854-624X

Tujuan penelitian adalah mengkaji faktor usia, tingkat pendidikan, tingkat pengetahuan, sikap dan pesan informasi terhadap perilaku penerapan protokol kesehatan $3 \mathrm{M}$ dalam memutus mata rantai.

\section{BAHAN DAN METODE}

Jenis penelitian yang di gunakan adalah kuantitatif dengan metode pendekatan cross sectional study yang bermaksud mengetahui pengaruh usia,pendidikan, pengetahuan, sikap dan pesan informasi dengan factor yang mempengaruhi kepatuhan protokol kesehatan $5 \mathrm{M}$ di Pasar Todopuli Kota Makassar.

Tekhnik penarikan sampel adalah accidental sampling yaitu, penentuan sampel berdasarkan kebetulan, yakni sampel yang ditemui pada saat penelitian berlangsung. Sampel dalam penelitian ini adalah pedagang pasar selama penelitian ini berlangsung sejumlah 108 orang.

\section{HASIL}

Berdasarkan tabel1, menujukkan bahwa usia remaja $(36,1 \%)$, usia dewasa (63,9\%), Pendidikan tinggi (47,2\%), pendidikan rendah $(52,8 \%)$, Pengetahuan cukup (62,0\%), Pengetahuan kurang $(38,0 \%)$, Sikap positif $(65,7 \%)$, Sikap negative (34,3\%), Mendapat pesan informasi cukup $(72,2 \%)$, mendapat pesan informasi kurang (27,8\%).

Berdasarkan tabel 2, menunjukkan bahwa dari 39 responden remaja, yaitu 21 orang $(53,8 \%)$ dan yang patuh terhadap Protokol Kesehatan 5M, dan 18 orang $(46,2 \%)$ yang tidak patuh. Sedangkan dari 69 Responden dewasa, yang patuh terhadap Protokol Kesehatan 5M yaitu 19 orang $(27,5 \%)$ dan yang tidak patuh terhadap protokol kesehatan yaitu 50 orang $(46,7 \%)$.

Hasil uji statistik dengan menggunakan nilai person chi-square (Fisher's Exact Test) diperoleh nilai $\rho=$ 0.008 dimana $\rho<\alpha(\alpha=0.05)$ maka Ho ditolak dan Ha diterima, Ada Pengaruh usia terhadap Kepatuhan Protokol Kesehatan $5 \mathrm{M}$ di Pasar tradisional Todopuli Kota Makassar.

Berdasarkan tabel 3, menunjukkan bahwa dari 51 responden berpendidikan tinggi, ada 25 orang $(49,0 \%)$ yang patuh terhadap Protokol Kesehatan 5M, dan 26 orang $(51,0 \%)$ yang tidak patuh. Sedangkan dari 57 Responden berpendidikan rendah, yang patuh terhadap Protokol Kesehatan 5M yaitu
15 orang $(26,3 \%)$ dan yang tidak patuh terhadap protokol kesehatan yaitu 42 orang (73,7\%).

Hasil uji statistik dengan menggunakan nilai person chi-square (Fisher's Exact Test) diperoleh nilai $\rho=$ 0.017 dimana $\rho<\alpha(\alpha=0.05)$ maka Ho ditolak dan $\mathrm{Ha}$ diterima, Ada pengaruh pendidikan terhadap Kepatuhan Protokol Kesehatan 5M di Pasar tradisional Todopuli Kota Makassar.

Berdasarkan tabel 4, menunjukkan bahwa dari 67 responden berpengetahuan cukup, ada 19 orang $(28,4 \%)$ yang patuh terhadap Protokol Kesehatan 5M, dan 48 orang $(71,6 \%)$ yang tidak patuh. Sedangkan dari 57 Responden berpengetahuan kurang, yang patuh terhadap Protokol Kesehatan $5 \mathrm{M}$ yaitu 21 orang $(51,2 \%)$ dan yang tidak patuh terhadap protokol kesehatan yaitu 20 orang $(48,8 \%)$.

Hasil uji statistik dengan menggunakan nilai person chi-square (Fisher's Exact Test) diperoleh nilai $\rho=$ 0.024 dimana $\rho<\alpha(\alpha=0.05)$ maka Ho ditolak dan $\mathrm{Ha}$ diterima, Ada pengaruh pengetahuan terhadap Kepatuhan Protokol Kesehatan 5M di Pasar tradisional Todopuli Kota Makassar.

Berdasarkan tabel 5, menunjukkan bahwa dari 71 responden bersikap positif, ada 21 orang $(29,6 \%)$ yang patuh terhadap Protokol Kesehatan 5M, dan 50 orang $(70,4 \%)$ yang tidak patuh. Sedangkan dari 37 Responden bersikap negative, yang patuh terhadap Protokol Kesehatan 5M yaitu 19 orang $(51,4 \%)$ dan yang tidak patuh terhadap protokol kesehatan yaitu 18 orang $(48,6 \%)$.

Hasil uji statistik dengan menggunakan nilai person chi-square (Fisher's Exact Test) diperoleh nilai $\rho=$ 0.036 dimana $\rho<\alpha(\alpha=0.05)$ maka Ho ditolak dan $\mathrm{Ha}$ diterima, Ada pengaruh pendidikan terhadap Kepatuhan Protokol Kesehatan 5M di Pasar tradisional Todopuli Kota Makassar.

Berdasarkan tabel 6, menunjukkan bahwa dari 78 responden mendapat pesan informasi cukup, ada 24 orang $(30,8 \%)$ yang patuh terhadap Protokol Kesehatan $5 \mathrm{M}$, dan 54 orang $(69,2 \%)$ yang tidak patuh. Sedangkan dari 30 Responden mendapat pesan informasi kurang, yang patuh terhadap Protokol Kesehatan 5M yaitu 16 orang $(53,3 \%)$ dan yang tidak patuh terhadap protokol kesehatan yaitu 14 orang $(46,7 \%)$. 
Jurnal Sulolipu : Media Komunikasi Sivitas Akademika dan Masyarakat

Vol. 21 No.2 2021

e-issn : 2622-6960, p-issn : 0854-624X

Hasil uji statistik dengan menggunakan nilai person chi-square (Fisher's Exact Test) diperoleh nilai $\rho=$ 0.044 dimana $\rho<\alpha(\alpha=0.05)$ maka Ho ditolak dan $\mathrm{Ha}$ diterima, Ada pengaruh pendidikan terhadap Kepatuhan Protokol Kesehatan 5M di pasar tradisional Todopuli Kota Makassar.

Berdasarkan Tabel Variables in The Equation Nilai Constant $(\mathrm{B} 0)=-2,423$, Nilai Koefisien regresi logistic untuk variabel independen Pengetahuan $(B 1)=1,067$ Sikap (B2) $=1,104$, Pendidikan (B4) $=, 880$, pesan informasi dari satgas covid19(B5) $=1,663$ Dengan memperhatikan nilai Sig. menujukkan bahwa variabel pesan informasi dengan nilai $\rho=0,004 . P<0.05$ ini berarti variabel pesan informasi merupakan variabel yang paling berpengaruh terhadap kepatuhan protokol kesehatan 5M.

\section{PEMBAHASAN}

Umur adalah satu factor yang menggambarkan kematangan fisik, psikis dan social serta setidaknya berpengaruh dalam proses pembelajaran (Kartika, 2021). Meningkatnya umur membuat seseorang semakin matang atau dewasa dan rasa tanggung jawab dan keperdulianya meningkat. Pedagang yang memiliki umur lebih dewasa rasa tanggung jawab dan keperdulian terhadap diri sendiri dan lingkungan meningkat. Para pedagang menggerakkan untuk menjaga kebersihan dagangan dan lingkungan serta menerapkan $5 \mathrm{M}$ di pasar tradisional Todopuli Kota Makassar.

Tingkat pendidikan pedagang yang rendah akan berhubungan dalam proses analisis sebuah informasi yang diperoleh yang diwujudkan dalam sebuah tindakan. Hasil penelitian menunjukkan bahwa semakin tinggi jenjang pendidikan responden maka responden akan semakin patuh dalam penerapan protokol kesehatan Covid-19. (Cinthya, 2020) menyatakan bahwa semakin tinggi pendidikan seseorang maka akan berpengaruh terhadap pelaksanaan kesehatan masyarakat, rendahnya pendidikan seseorang akan menyebabkan kurangnya kesadaran orang tersebut dalam peningkatan kesehatannya. Semakin baik pendidikan formal seseorang akan meningkatkan pemahaman orang tersebut tentang pentingnya kesehatan sehingga hal ini akan mempengaruhi kesadaran perilaku kesehatannya. Amalia Imanda, (2019) juga menyatakan pendapat yang sama yakni menyatakan bahwa pendidikan sangat berpengaruh terhadap pencegahan penyakit di lingkungan pasar. Pendidikan yang tinggi akan menpengaruhi pola pikir seseorang terhadap pencegahan penyakit dengan penerapan perilaku hidup bersih dan sehat di pasar kliwon dan Jebres Kota Surakarta (Anggreni, 2020). Hasil penelitian ini sejalan dengan penelitian yang menyampaikan terdapat hubungan tingkat pendidikan dan kepatuhan protokol kesehatan pada masyarakat Sulawesi Utara (Gabbikaa \& Sembiring, 2020).

Pengetahuan pedagang sebagai faktor predisposisi yang dapat membentuk perilaku pedagang dalam menerapkan protokol kesehatan. Pengetahuan yang baik akan sebuah kebiajakan akan mendukung pelaksanaan kebijakan tersebut, dan sebaliknya pengetahuan yang kurang baik akan berdampak negatife terhadap kebijakan tersebut (Adliyani et al., 2017; Notoatmodjo, 2005). Pengetahuan yang baik biasanya dipengaruhi oleh tingkat pendidikan yang tinggi. Semakin tinggi tingkat pendidikan seseorang maka orang tersebut akan semakin aktif dalam mencari informasi-informasi

(Notoatmodjo, 2005; Putri, 2017).

Siswani dan Rizki (2018) menyatakan bahwa pengetahuan memiliki pengaruh yang signifikan terhadap pelaksanaan pencegahan penyakit dengan penerapan PBHS. Semakin baik dan semakin benar pemahaman atau pengetahuan individu tentang masalah kesehatan maka akan semakin baik juga tindakan individu dalam pencegahan penyakit tersebut (Siswani \& Rizky, 2018). Dalam penelitian ini, peneliti menemukan bahwa kurang baiknya pemahaman pedagang tentang Covid-19 maka hal tersebut mengakibatkan pedagang masih mengabaikan protokol kesehatan Covid-19. Peningkatan pengetahuan pedagang diperlukan agar pedagang selalu menerapkan protokol kesehatan Covid-19 sehingga pedagang dapat mencegah tertular penyakit Covid-19. Peningkatan pengetahuan pedagang pasar terkait covid19 dapat mendorong untuk patuh dalam mengikuti segala protokol kesehatan yang lebih diterapakan, hal ini juga didukung oleh Ahmadi (2013) yang menyatakan bahwa seseorang yang memiliki pengetahuan tentang sesuatu informssi maka akan mampu menetukan dan mengambil 
Jurnal Sulolipu : Media Komunikasi Sivitas Akademika dan Masyarakat

Vol. 21 No.2 2021

e-issn : 2622-6960, p-issn : 0854-624X

keputusan dalam menghadapi suatu permasalahan atau dengan kata lain para pedagang yang memiliki pengetahuan tentang covid-19 maka akan mampu menetukan bagaimana dirinya harus berperilaku dalam menghadapi penyakit tersebut.

Berdasarkan hasil penelitian dilapangan peneliti berasumsi bahwa semakin buruk sikap individu terhadap pencegahan penyakit maka akan semakin buruk juga tindakan yang individu lakukan. Hasil ini didukung oleh penelitian Yanti,dkk (2020) dengan hasil menunjukan bahwa mayoritas masyarakat memiliki tingkat pengetahuan yang baik $(70 \%)$ tentang covid-19. Hasil yang sama diperoleh Purnamasari dan Anisa (2020) dimana masyarakat cenderung memiliki sikap yang positif dalam menghadapi covid-19 (59\%). Wiranti, Ayun dan Wulan (2020) juga mempertegas hasil penelitian yang didapat dimana masyarakat juga sudah dominan menghadapi covid-19.

Berdasarkan hasil penelitian dilapangan peneliti berasumsi bahwa tidak semua pesan informasi yang diperoleh pedagang dijadikan sebagai suatu bentuk pengetahuan yang berguna dalam penerapan protokol kesehatan Covid-19. $\mathrm{Hal}$ ini sesuai dengan penelitian yang dilakukan oleh Nurmansyah dkk (2012) yang mengatakan bahwa tidak semua pesan informasi dimanfaatkan dalam peningkatan pengetahuan. Dalam penelitian ini juga dapat kita ketahui bahwa walaupun pesan informasi pedagang sudah baik namun dalam hal penerapan nya pedagang belum secara sadar dalam menerapkan protokol kesehatan Covid-19 untuk mencegah penularan penyakit Covid-19.

\section{KESIMPULAN}

1. Usia berhubungan dengan kepatuhan protokol $5 \mathrm{M}$ di pasar tradisional Todopuli Kota Makassar.

2. Pendidikan berhubungan dengan kepatuhan protokol $5 \mathrm{M}$ di pasar tradisional Todopuli Kota Makassar.

3. Pengetahuan berhubungan dengan kepatuhan protokol $5 \mathrm{M}$ di Pasar tradisional Todopuli Kota Makasar.

4. Sikap berhubungan dengan kepatuhan protokol $5 \mathrm{M}$ di Pasar tradisional Todopuli Kota Makassar.

5. Pesan Informasi berhubungan dengan Kepatuhan Protokol $3 \mathrm{M}$ di Pasar tradisional Todopuli Kota Makassar.

\section{DAFTAR PUSTAKA}

Agus. (2020). Empat Strategi Pemerintah Atasi COVID-19. diakses pada 3 Agustus 2020 dari https://covid19.go.id/p/berita/empatstrategi-pemerintah-atasi-covid-19.

Adi P, 2020. Pengaruh Pendidikan Kesehatan dengan Media Leaflet untuk Meningkatkan Pengetahuan dan Perilaku dalam Upaya Menerapkan Protokol Kesehatan pada Pedagang di Car Free Day Temanggung. Jurnal Ilmiah Kesehatan

Anggreni, 2020. Hubungan Pengetahuan tentang Covid-19 dengan Kepatuhan dalam Menerapkan Protokol Kesehatan di Masa New Normal. Hospital Majapahit.Vol 12 No. 2 November 2020

Budury, 2020. /Faktor yang Berhubungan dengan Penerapan Protokol Penendalian Covid-19 pada Mahasiswa Keperawatan. Jurnal Keperawatan Volume 12 No 14,Hal 751756, Desember 2020.Sekolah Tinggi Ilmu Kesehatan Kendal.

Cinthya, 2020. / Analisis Faktor Memengaruhi Kepatuhan terhadap Protokol Kesehatan saat Pandemi Covid-19 pada Masyarakat Jawa Timur: Pendekatan Health Belief Model.Jurnal $\mathrm{CMH}$ (Jurnal Of Communy Mental Healtf and Publicy).

Devi Pramita Sari \& Nabila Sholihah 'Atiqoh. (2020 . HUBUNGAN ANTARA PENGETAHUAN MASYARAKAT DENGAN KEPATUHAN PENGGUNAAN MASKER SEBAGAI UPAYA PENCEGAHAN PENYAKIT COVID-19 DI NGRONGGAH.

Infokes: Jurnal IImiah Rekam Medis dan Informatika Kesehatan, 10(1), 52-55. https://doi.org/10.47701/infokes.v10i1.850 
Jurnal Sulolipu : Media Komunikasi Sivitas Akademika dan Masyarakat

Vol. 21 No.2 2021

e-issn : 2622-6960, p-issn : 0854-624X

Diva Putra et al, 2020. /Gambaran Karakteristk Pengetahuan, Sikap dan Perilaku Risiko Covid19 dalam Kerangka Desa Adat di Desa Gulingan,Mengwai, Bali.http:/Jurnal.fk.unand.ac.id

Erfani, 2020. Knowledge, Attitude and Practice toward the Novel Coronavirus (COVID-19) Outbreak:A Population-Based Survay in Iran.http://dx.doi.org /10.2471/BLT.20.251561).

Fuadi, T. M. \& Irdalisa. (2020). Covid 19: Antara Angka Kematian dan Angka Kelahiran. Jurnal Sosiologi Agama Indonesia (JSAl), 1(3), 199-211. https://doi.org /10.22373/jsai.v1i3.767

Ghiffari, 2020. Faktor-Faktor yang Mempengaruhi Ketindakpatuhan Masyrakat Menggunakan Masker pada saat Pandemi Covid-19 di Palembang. Seminar Nasional Syedza Saintika.ISSN:2775-3550

Hamidi, S., \& Zandiatashbar, A. (2021). Compact development and adherence to stay-at-home order during the COVID-19 pandemic: A longitudinal investigation in the United States. Landscape and Urban Planning, 205, $103952 . \quad$ https://doi.org /10.1016/j.landurbplan.2020.103952

Herniwanti, H., Dewi, O., Yunita, J., \& Rahayu, E. P. (2020). Penyuluhan Perilaku Hidup Sehat Dan Bersih (PHBS) dan Gerakan Masyarakat Hidup Sehat (GERMAS) kepada Lanjut Usia (LANSIA) Menghadapi Masa Pandemi Covid 19 dan New Normal dengan Metode 3M. Jurnal Abdidas, 1(5), 363-372. https://doi.org /10.31004/abdidas.v1i5.82

Istanti, N., \& Erlita, Y. D. (2021). Volume 13 Nomor 1, Maret 2021 e-ISSN 2549-8118; pISSN 2085-1049 http://journal.stikeskendal.ac.id J, R., Jm, L., L, L., C, L., R, G., E, du R., \& P, A. (2020). Determinants of Preventive Behaviors in Response to the COVID-19 Pandemic in France: Comparing the Sociocultural, Psychosocial, and Social Cognitive Explanations.

Kartika, 2021. Identifikasi Penyebab Ketidakpatuhan Warga terhadap Penerapan Protokol Kesehatan 3M di Masa Pandemi Covid- 19 (Studi Kasus Pelanggar Protokol Kesehatan $3 \mathrm{M}$ di Ciracas Jakarta Timur). Yayasan Akrab Pekanbaru.Jurnal AKRAB JUARA. Volume 6 Nomor 1 Edisi Februari 2021(84-94)

Kresna, 2020. Pengaruh Physical Distancing dan Social Distancing terhadap Kesehatan dalam Pendekatan Linguistik.Jurnal Syntax Transformation Vol.1 No.2, Juni 2020

Luknis, S., \& Sutanto, P. H. (2008). Statistik Kesehatan. Rajawali Pers. Moudy, J., \& Syakurah, R. A. (2020). Pengetahuan terkait Usaha Pencegahan Coronavirus Disease (COVID19) di Indonesia. A. S.,

Mujani, S., \& Irvani, D. (2020). Sikap dan Perilaku Warga terhadap Kebijakan Penanganan Wabah Covid-19. Politika: Jurnal Ilmu Politik, 11(2), 219-238. https://doi.org /10.14710/politika.11.2.2020.219-238

Naser, A. Y., Dahmash, E. Z., Alwafi, H., Alsairafi, Z. K., Rajeh, A. M. A., Alhartani, Y. J., Turkistani, F. M., \& Alyami, H. S. (2020). "Knowledge and practices towards COVID-19 during its outbreak: A multinational cross-sectional study" [Preprint]. Infectious Diseases (except HIV/AIDS). https://doi.org/10.1101/2020.04.13.20063560

Notoatmodjo, S. (2005). Metode Penelitian Kesehatan (3rd ed.). Rineka Cipta.

Notoatmodjo, S. (2012). Pendidikan dan Perilaku Kesehatan. Rineka Cipta.

Notoatmodjo, S. (2013). Ilmu Kesehatan Masyarakat. Rineka Cipta. 
Jurnal Sulolipu : Media Komunikasi Sivitas Akademika dan Masyarakat

Vol. 21 No.2 2021

e-issn : 2622-6960, p-issn : 0854-624X

Oyeyemi, O., Oladoyin, V., Okunlola, O., Mosobalaje, A., Oyeyemi, I., Adebimpe, W., Nwuba, R., Anuoluwa, I., Tiamiyu, A., Ovuakporie- uvo, O., Adesina, I., Olatunji, B., Kone, J., Oluwafemi, Y., Obajaja, C., \& Ajiboye, A. (2020). COVID-19 pandemic: Nigerians' knowledge, perception and adherence to preventive measures [Preprint]. In Review. https://doi.org/10.21203/rs.3.rs-49707/v1 Purnamasari, I., \& Raharyani, A. E. (2020). Jurnal IImiah Kesehatan 2020.

$\begin{array}{lll}\text { Seminar Nasional Official Statistics, 2020(1), 45-54. https://doi.org } & \end{array}$ /10.34123/semnasoffstat.v2020i1.431

Stang. (2014). Cara Praktis Penentuan Uji Statistik dalam Penelitian Kesehatan dan Kedokteran (1st ed.). Universitas Hasanuddin, Mitra Wacana Medika.

Stang. (2017). Aplikasi Statistik Multivariat dalam Penelitian Kesehatan. Universitas Hasanuddin Mitra Wacana Medika.

Sulawesi Selatan Tanggap Covid-19. https://covid19.sulselprov.go.id. Diakses pada tanggal 20 Agustus 2021.

Utami, R. A., Mose, R. E., \& Martini, M. (2020). Pengetahuan, Sikap dan Keterampilan Masyarakat dalam Pencegahan COVID-19 di DKI Jakarta. Jurnal Kesehatan Holistic, 4(2), 68-77. https://doi.org /10.33377/jkh.v4i2.85

Yang, Y., Peng, F., Wang, R., Guan, K., Jiang, T., Xu, G., Sun, J., \& Chang, C. (2020). The deadly coronaviruses: The 2003 SARS pandemic and the 2020 novel coronavirus epidemic in China. Journal of Autoimmunity, 109, $102434 . \quad$ https://doi.org /10.1016/j.jaut.2020.102434 
Jurnal Sulolipu : Media Komunikasi Sivitas Akademika dan Masyarakat

Vol. 21 No.2 2021

e-issn : 2622-6960, p-issn : 0854-624X

Lampiran

Tabel 1: Karakteristik Responden Pedagang Pasar Tradisional Todopuli Kota Makassar

\begin{tabular}{ccc}
\hline Karakteristik Responden & Frekuensi (f) & $\%$ \\
\hline Usia & & \\
\hline Remaja & 39 & 36,1 \\
Dewasa & 69 & 63,9 \\
\hline Pendidikan & & \\
\hline Tinggi & 51 & 47,2 \\
Rendah & 57 & 52,8 \\
\hline Pengetahuan & & 62,0 \\
Cukup & 67 & 38,0 \\
Kurang & 41 & 65,7 \\
\hline Sikap & & 34,3 \\
\hline Positif & 71 & 72,2 \\
Negatif & 36 & 27,8 \\
\hline Pesan Informasi & & 100,0 \\
\hline Cukup & 78 & \\
\hline Kurang & 30 & \\
\hline Jumlah & 108 & \\
\hline
\end{tabular}

Data Primer 2021

Tabel 2; Distribusi Pengaruh Usia terhadap Kepatuhan Protokol Kesehatan 5M Di Pasar Tradisional Todopuli Kota Makassar.

\begin{tabular}{|c|c|c|c|c|c|c|c|}
\hline \multirow{3}{*}{ Usia } & \multicolumn{4}{|c|}{$\begin{array}{l}\text { Kepatuhan protokol kesehatan } \\
5 \mathrm{M}\end{array}$} & \multirow{2}{*}{\multicolumn{2}{|c|}{ Total }} & \multirow{3}{*}{$\rho$-value } \\
\hline & \multicolumn{2}{|l|}{ Patuh } & \multicolumn{2}{|c|}{ Tidak patuh } & & & \\
\hline & $\mathrm{n}$ & $\%$ & $\mathrm{n}$ & $\%$ & $\mathrm{n}$ & $\%$ & \\
\hline Remaja & 21 & 53,8 & 18 & 46,2 & 39 & 100 & \\
\hline Dewasa & 19 & 27,5 & 50 & 46,7 & 69 & 100 & 0.008 \\
\hline Jumlah & 40 & 37,0 & 68 & 63,0 & 108 & 100 & \\
\hline
\end{tabular}

Data Primer 2021

Tabel 3; Distribusi Pengaruh Pendidikan terhadap Kepatuhan Protokol Kesehatan 5M Di Pasar Tradisional Todopuli Kota Makassar.

\begin{tabular}{|c|c|c|c|c|c|c|c|}
\hline \multirow{3}{*}{ Pendidikan } & \multicolumn{4}{|c|}{$\begin{array}{l}\text { Kepatuhan protokol kesehatan } \\
5 \mathrm{M}\end{array}$} & \multirow{2}{*}{\multicolumn{2}{|c|}{ Total }} & \multirow{3}{*}{$\rho$-value } \\
\hline & \multicolumn{2}{|c|}{ Patuh } & \multicolumn{2}{|c|}{ Tidak patuh } & & & \\
\hline & $\mathrm{n}$ & $\%$ & $\mathrm{n}$ & $\%$ & $\mathrm{n}$ & $\%$ & \\
\hline Tinggi & 25 & 49,0 & 26 & 51,0 & 51 & 100 & \\
\hline Rendah & 15 & 26,3 & 42 & 73,7 & 57 & 100 & 0.017 \\
\hline Jumlah & 40 & 37,0 & 68 & 63,0 & 108 & 100 & \\
\hline
\end{tabular}

Data Primer 2021 
Jurnal Sulolipu : Media Komunikasi Sivitas Akademika dan Masyarakat

Vol. 21 No.2 2021

e-issn : 2622-6960, p-issn : 0854-624X

Tabel 4; Distribusi Pengaruh Pengetahuan terhadap Kepatuhan Protokol Kesehatan 5M Di Pasar Tradisional Todopuli Kota Makassar.

\begin{tabular}{|c|c|c|c|c|c|c|c|}
\hline \multirow[t]{3}{*}{ Pengetahuan } & \multicolumn{4}{|c|}{$\begin{array}{l}\text { Kepatuhan protokol kesehatan } \\
5 \mathrm{M}\end{array}$} & \multirow{2}{*}{\multicolumn{2}{|c|}{ Total }} & \multirow[t]{3}{*}{$\rho$-value } \\
\hline & \multicolumn{2}{|l|}{ Patuh } & \multicolumn{2}{|c|}{ Tidak patuh } & & & \\
\hline & $\mathrm{n}$ & $\%$ & $\mathrm{n}$ & $\%$ & $n$ & $\%$ & \\
\hline Cukup & 19 & 28,4 & 48 & 71,6 & 67 & 100 & \\
\hline Kurang & 21 & 51,2 & 20 & 48,8 & 41 & 100 & 0.024 \\
\hline Jumlah & 40 & 37,0 & 68 & 63,0 & 108 & 100 & \\
\hline
\end{tabular}

Data Primer 2021

Tabel 5; Distribusi Pengaruh Sikap terhadap Kepatuhan Protokol Kesehatan 5M Di Pasar Tradisional Todopuli Kota Makassar.

\begin{tabular}{|c|c|c|c|c|c|c|c|}
\hline \multirow{3}{*}{ Sikap } & \multicolumn{4}{|c|}{$\begin{array}{l}\text { Kepatuhan protokol kesehatan } \\
5 \mathrm{M}\end{array}$} & \multirow{2}{*}{\multicolumn{2}{|c|}{ Total }} & \multirow{3}{*}{$\rho$-value } \\
\hline & \multicolumn{2}{|c|}{ Patuh } & \multicolumn{2}{|c|}{ Tidak patuh } & & & \\
\hline & $\mathrm{n}$ & $\%$ & $\mathrm{n}$ & $\%$ & $\mathrm{n}$ & $\%$ & \\
\hline Positif & 21 & 29,6 & 50 & 70,4 & 71 & 100 & \\
\hline Negatif & 19 & 51,4 & 18 & 48,6 & 37 & 100 & 0.036 \\
\hline Jumlah & 40 & 37,0 & 68 & 63,0 & 108 & 100 & \\
\hline
\end{tabular}

Data Primer 2021

Tabel 6; Distribusi Pengaruh Pesan Informasi terhadap Kepatuhan Protokol Kesehatan 5M Di Pasar Tradisional Todopuli Kota Makassar.

\begin{tabular}{|c|c|c|c|c|c|c|c|}
\hline \multirow[t]{3}{*}{ Pesan Informasi } & \multicolumn{4}{|c|}{$\begin{array}{l}\text { Kepatuhan protokol kesehatan } \\
5 \mathrm{M}\end{array}$} & \multirow{2}{*}{\multicolumn{2}{|c|}{ Total }} & \multirow[t]{3}{*}{$\rho$-value } \\
\hline & \multicolumn{2}{|c|}{ Patuh } & \multicolumn{2}{|c|}{ Tidak patuh } & & & \\
\hline & $\mathrm{n}$ & $\%$ & $\mathrm{n}$ & $\%$ & $\mathrm{n}$ & $\%$ & \\
\hline Cukup & 24 & 30,8 & 54 & 69,2 & 78 & 100 & \\
\hline Kurang & 16 & 53,3 & 14 & 46,7 & 30 & 100 & 0.044 \\
\hline Jumlah & 40 & 37,0 & 68 & 63,0 & 108 & 100 & \\
\hline
\end{tabular}

Data Primer 2021

Tabel 7; Analisis Regresi Logistik Pengaruh Variabel terhadap Kepatuhan Protokol Kesehatan 5M Di Pasar Tradisional Todopuli Kota Makassar.

$$
\text { B S.E. Wald df Sig. } \operatorname{Exp(B)~} \begin{aligned}
& 95 \% \text { C.I.For } \\
& \operatorname{EXP(B)}
\end{aligned}
$$

\begin{tabular}{lllllllll} 
& & & & & & & Lower & Upper \\
\hline Usia & $-2,136$ &, 578 & 13,658 & 1 &, 000 &, 118 &, 038 &, 367 \\
\hline Pendidikan &, 880 &, 507 & 3,006 & 1 &, 083 & 2,410 &, 892 & 6,513 \\
\hline Pengetahuan & 1,067 &, 484 & 4,860 & 1 &, 027 & 2,907 & 1,126 & 7,509 \\
\hline Sikap & 1,104 &, 540 & 4,173 & 1 & .041 & 3,015 & 1,046 & 8,694 \\
\hline $\begin{array}{l}\text { Pesan } \\
\text { Informasi }\end{array}$ & 1,663 &, 578 & 7,665 & 1 &, 004 & 5,273 & 1,699 & 16,382 \\
\hline Constant & $-2,423$ &, 875 & 4,800 & 1 &, 006 &, 089 & & \\
\hline
\end{tabular}

